\title{
$\mathrm{BIO} / \mathrm{Ag}$. $V$ \& $E$ \\ UC-NRLF \\ B 4 b51 554
}

SB

388

W45 


\section{THE VINEYARDS OF}

THE WORLD

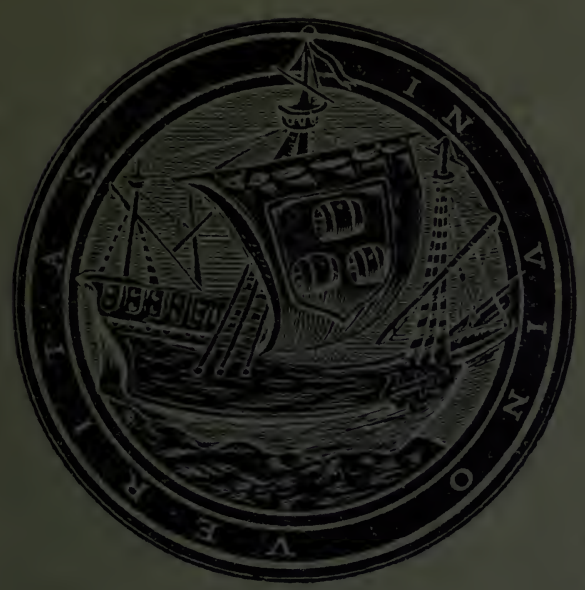

THE WINE TRADE CLUB, 4I, SEETHING LANE, LONDON, E.C.

IgI2

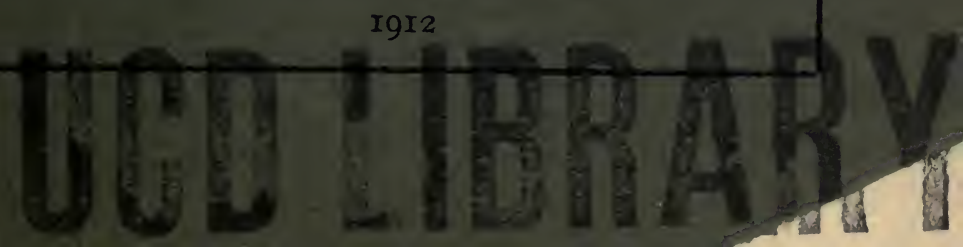




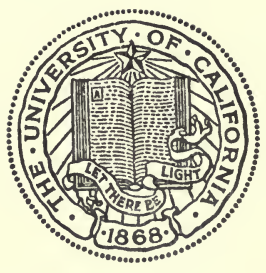

THE LIBRARY OF

\section{THE UNIVERSITY OF CALIFORNIA DAVIS}

GIFT OF

MAYNARD A. AMERINE 


\section{THE VINEYARDS OF}

THE WORLD.

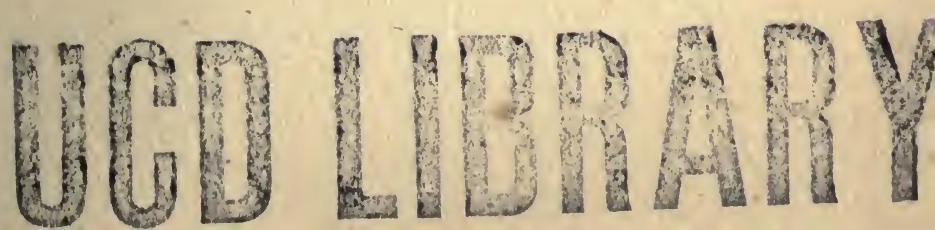


Digitized by the Internet Archive in 2007 with funding from Microsoft Corporation 


\section{THE VINEYARDS OF THE WORLD.}

T ONG before the earth had become habitable, before any sign of animal life had appeared either on land or in the seas, the wild Vine grew from pole to pole, in the warm equable temperature which then enveloped the whole globe. At Brjamslak, in Iceland ; at Bovey Tracey, in Devonshire; at Sézanne (Marne), in France; in Silesia; in the valley of the Rhine; in Switzerland and in many other parts of Europe as well as in America, fossils have been found, which modern palæontology enables us to recognise as 


\section{THE VINEYARDS OF THE WORLD.}

dating back to the earliest stages of the crust formation of the earth, and which show distinct impressions of the leaves of different species of wild Vines. Modern science, in this instance, is only confirming the teachings of the book of Genesis, where we read how the Vegetable preceded the Animal Kingdom in the order of creation.

We further learn from Holy Writ how Noah planted a vineyard, and how he drank wine and fell to sleep. There is no suggestion, however, that he was the first man who ever drank wine: the fact that he was overcome by it is only incidentally mentioned to bring home the lesson of the undutiful son's conduct and punishment. But, whatever opinions one may have on this point, the fact remains that wine, the naturally fermented juice of the grape, and therefore alcoholic and inebriating when taken to excess, was known, used, and 
THE VINEYARDS OF THE WORLD. 5 abused, at the earliest known periods of the history of the human race.

Whether it be Osiris, in Egypt ; Varum, in India; Samschid, in Persia; Eleusis and Bacchus, in Greece and in Rome; we find in all the oldest legends of the East and the mythology of the Ancients, a benevolent divinity who was credited with having introduced viticulture and civilisation. It may truly be said that in every part of the world and among every race, the use of wine is older than the oldest records which have reached us.

Pickett, in his Origines Indo-Européennes, states that the Aryans introduced viticulture in Egypt, India, Persia, and Greece; this is also the opinion advanced by Pietro Selleh in his Trattato di Viticultura e di Vinificazione. On the other hand, we are told by Sir John Malcolm, in his History of Persia, that viticulture was 
6 THE VINEYARDS OF THE WORLD.

already flourishing in Persia in the reign of King Jensheed, a monarch who is believed to have lived at a very remote date and who is credited with the discovery of fermentation. One of his successors, about the year 3000 B.C., is reported to have undertaken the conquest of the island of Cyprus, because it contained a treasure which a mighty King ought to possess : Wine.

In Egypt, we have more than mere tradition to rely upon for records of the greatest antiquity. Delchevalerie, in his Illustration Horticole, depicts the scenes of grape-gathering and wine-making which ornament the tomb of Phtah-Hotep, who lived in Memphis, some 4000 years before Christ. Pickering, in his Chronological History of Plants, has reproduced similar glyptic illustrations which he ascribes to the Third Egyptian Dynasty, adding that 
THE VINEYARDS OF THE WORLD. 7 other representations of Vineyards and full details of the art of wine-making belong to the Fourth, Seventeenth, and Eighteenth Dynasties. Quite recently, the laws of Khammurabi, King of Babylon about B.c. 2250, have been discovered and decyphered and have aroused a great deal of interest. This Sovereign appears to have been the great legislator of his dynasty; his laws contain the most precise regulations concerning the sale of wine, and show us the poor retailer of wine to have been harassed by a very severe legislation even in those times. Fines were not in vogue then, but the loss of a limb or of life was the penalty incurred by the seller of wine giving bad quality or short measure or allowing riotous conduct on the premises.

In China, viticulture flourished from 2000 B.c. until the fourteenth century of our era, whilst in Europe and in Africa 


\section{THE VINEYARDS OF THE WORLD.}

the Phœnicians seem to have taught the art of wine-making in the Peloponese, the Latium, Gaul and the Iberic Peninsula, as well as all along the Mediterranean coast of Africa where they had Colonies.

The earliest records of ancient Greek and Latin history show that the cultivation of Vineyards and the science of winemaking are coeval with the dawn of civilisation in Greece, the Balkans, Italy, France, Spain, Portugal, Germany, and Britain. Modern discoveries of the lakedwellings of the Bronze Age, at Castione, near Parma, at Bex, at Wangen and at Varese, prove the vine to have been indigenous to Europe and that at the remotest date of Western History of which we thus possess documentary evidence, men grew corn and vines. Professor Heer, in his Die Pflanzen der Pfahlbauten, even asserts that he has been able to distinguish in some 
THE VINEYARDS OF THE WORLD. 9

lacustrine remains, evidence of both wild and cultivated grapes.

The Phœnicians, Greeks and Romans of old, appear to have all realised the civilising influence of viticulture. Wherever they obtained a sufficiently secure footing in a new country, they taught the "Barbarians" to plant and tend vines. In more modern times, the same policy has been followed by the early Christian missionaries who, wherever they went and whenever they were able to build a Church or a Monastery as a permanent abode, taught the heathens the gentle art of viticulture. Some of the choicest vineyards of France and Germany retain to this day names recalling their ecclesiastical origin. In Britain, too, it was the early Christian priests who taught the Saxons how to grow vines where no other crop could be raised and, under their guidance, vineyards were 
IO THE VINEYARDS OF THE WORLD.

planted not only on Kentish chalk and Surrey gravel, but in almost every part of the country, as far North as Scotland.

In more recent times, it was the successors of those early Christian priests who also taught the art of viticulture all along the Pacific coast, from California and Mexico to Peru and Chili.

It is true that the Vineyards of Britain, if we except those of the Marquis of Bute, in Wales, and of the Royal Horticultural Society, in Surrey, have long ceased to exist, as well as those of Normandy, Belgium, and Northern Germany. This is not, however, because vines can no longer be grown in northern latitudes, but because it has been found more profitable for centuries past to obtain wine from those foreign lands where the climate, soil and cheaper labour, make it possible to produce 
THE VINEYARDS OF THE WORLD. II wine of better quality and at lower cost than the home produce.

The vine will grow in all but arctic and tropical latitudes, but its fruit will only mature to perfection in temperate countries.

To give an account of every Vineyard at present existing in the world is a task far too difficult to attempt and one which would greatly exceed the limits of our Lecture. We only wish to place before you some general remarks concerning the more important and more interesting Vineyards of the world, particularly those which produce the wines most popular in this country.

\section{France.}

Of all wine producing countries, France is unequalled not only for the quantity, but also for the quality and the great variety of wines she produces.

The country is divided into eighty-three 
I2 THE VINEYARDS OF THE WORLD.

"Départements" of which all, with the exception of the eight most northern, produce wine. The vintage of IgII was a very fine one as regards the quality of the wines made, but the quantity was greatly below the average. Official reports place the productions of wine in France last year at 987,482 , Ioo gallons, but these figures are not final, and we prefer, therefore, not to make use of them. As to the preceding year, the vintage of Igro was such an unprecedented failure that it does not give any fair idea of the yearly production of wine in France. If, however, we take the average of the three preceding years, I907, I908 and I909, none of which was remarkably good, we find that the yearly average production of wine in the country is over one milliard 300 million gallons of wine. By way of a comparison, it may be remarked that the average yearly 
THE VINEYARDS OF THE WORLD. I3 consumption of French wines in the United Kingdom is only about $3 \frac{1}{2}$ million gallons, and that whilst the consumption of wine in France is 26 gallons per head of the population, it is only a quarter of one gallon in England. It is also worthy of notice that, whilst the consumption of wine is 100 times greater in France than in England per head of the population, drunkenness is very seldom met with on the other side of the Channel and alcoholism is very much less prevalent amongst our neighbours than in our own country. This is all the more remarkable when one considers that France has never had the benefit of that large number of enthusiastic and energetic total abstinence Societies which have flourished in our midst so long and expended so much money and labour to combat drunkenness.

The vineyards of France which interest us most in England are those which produce 


\section{I4 THE VINEYARDS OF THE WORLD.}

Sparkling Champagne and Saumur, Cognac Brandy, Burgundies and Claret.

\section{Bordeaux.}

Ever since the fourth century, when Ausonius, who was born at Bordeaux in A.D. 309, tells us that they were in demand in Rome, the wines of Bordeaux have been shipped to every part of the Civilised World and have enjoyed a more universal and lasting reputation than any other wine. But not all the wines which have for so many centuries passed through Bordeaux on their way to distant and less-favoured lands, have been the produce of the Bordeaux vineyards. What we call Claret, in England, and what the French call Vin de Bordeaux is, or should be, the produce of the "Département" of the Gironde, and of no other. In all the neighbouring "Départements," vineyards have 
THE VINEYARDS OF THE WORLD. I5 existed for centuries past and still flourish ; the wines they produce, however, are not entitled to the name of Bordeaux because they are shipped from that port. They were known in England in mediæval times as red, white, or claret wines from Guienne, Gascony or Languedoc. The appellation "Claret" was originally used to designate the style and not the origin of the wine, but as practically the whole of the light red wines consumed in England came primarily from Bordeaux, the meaning of the name Claret became gradually restricted first to those red and white wines shipped from Bordeaux and later to the Bordeaux wines proper, or the produce of the Gironde. Custom having endowed the name of Claret with a strictly limited geographical meaning, it should not be used in conjunction with any other geographical appellation; it is as illogical to speak of California Claret, 
I6 THE VINEYARDS OF THE WORLD.

for instance, as of Tarragona Port or Italian Champagne.

The Département of the Gironde is part of the old Province of Gascony and produces a much greater quantity of fine red and white wines than any other Département.

The Vineyards of the Gironde may be divided into six principal districts, namely : (I) Médoc; (2) Graves; (3) Sauternes ; (4) Entre-deux-Mers; (5) Côtes ; and (6) Palus. All these districts are situated on the Garonne, on the Dordogne, or on their confluent, the Gironde, and produce an average of 9I,895,org gallons per annum.

I. The MEDOC is a strip of low lying land along the left bank of the River Gironde, some six miles wide and about 50 miles long. The best Vineyards are planted on a series of gently swelling elevations of varying heights, which may be likened to 
THE VINEYARDS OF THE WORLD. I7

some great downs, the soil of which is chiefly composed of silicious gravel and is sometimes of a calcareous nature.

The principal vineyards of the Medoc, as one leaves Bordeaux and proceeds towards the Bay of Biscay, lie in the districts of Ludon, Macau and Labarde, and on to Cantenac and Margaux, from the stony and gravelly soil of which are produced some of the most delicate and refined of all Clarets.

After passing through some few miles of flat country where richer alluvial soil is to be met and a somewhat poorer quality of wine is made, one comes to the Vineyards of St. Laurent, and the more famous district of St. Julien, in which Léoville, Larose and many other fine growths are situated. From there, one passes into the Yauillac district, where are to be found some of the finest Vineyards in all the Médoc. Here, near the old-fashioned 
I8 THE VINEYARDS OF THE WORLD.

village of Pauillac, on the banks of the broad river, are the celebrated Châteaux of Lafite and Latour, Mouton, Pichon Longueville and Pontet Canet, and more than a score of others, separated from each other and from less famous Vineyards merely by a road or even a path.

After leaving Château Lafite, one enters the St Estèphe district where there are fewer Châteaux, but where some very fine wine is also made. At St. Estèphe may be said to terminate the "Grands Crûs du Médoc," although there is a large quantity of good wine made in districts beyond.

2. Graves.-This district is smaller but more picturesque than the Médoc, beginning just outside Bordeaux and extending only thirteen miles to the south, and about five and a half miles to the west of the City. The soil is of a light sandy nature 
THE VINEYARDS OF THE WORLD. I9

full of silicious stones of different sizes and colour to a depth of from two to ten feet. The subsoil varies a good deal, and is either clay, chalk or stone, or formed of a hard kind of very dark sand, known as alios, which contains a ferrugineous matter called " arène." There, again, we have a soil absolutely unfit for any other culture but that of the Vine, which grows there and produces a wine the flavour and sweetness of which more than compensates for the usually small quantity of the yield. The Graves district produces red as well as white wines of very high repute, but the brightest jewel in its vinous crown, and one of which it is justly proud, is the Château Haut Brion, which stands at the very gates of Bordeaux.

3. SAuternes.-This is but a small district, comprising Sauternes, Bommes and Barsac, and dedicated almost entirely to 
20 THE VINEYARDS OF THE WORLD.

white wines. The soil differs from that of the Graves district, which it adjoins ; it is a mixture of clay and gravel partly, and clay and chalk.

The sunny Vineyards of Y'quem, at Sauternes, produce a naturally sweet wine, quite unique, and of unsurpassed excellence.

4. Entre-Deux-Mers.-This district is between the Garonne and the Dordogne and produces a great deal of good red and white wines.

5. Côtes.-The Côtes wines are those grown on the hills in several parts of the Gironde Département, and vary therefore greatly in quantity and quality. By far the finest Côtes wines are those of the St. Emilion district on the right bank of the Dordogne. This is quite the most attractive district of the Gironde as it is undulating and abounds in beautiful landscape whilst the old ruins of St. Emilion itself 


\section{THE VINEYARDS OF THE WORLD. 2I}

are of great beauty and archeological interest.

6. Palus.-The Palus wines are those produced by vineyards planted in rich alluvial soil either close to the banks of the Gironde, the Garonne, and the Dordogne, on islands in these rivers or in the plains. These vineyards give usually abundant crops but the quality of the wine made therefrom is distinctly inferior to the produce of any of the other Vineyards of the Gironde.

\section{Cognac.}

Cognac is the name of a small town, on the river Charente, in the heart of a winegrowing district which produces the finest Brandies in the World. As far back as the reign of King John, and for many centuries after, the wines of Saintonge, Aunis and Angoumois were shipped to England as Rochelle wines and sold at 
22 THE VINEYARDS OF THE WORLD.

cheaper rates than any others. These Wines were considered thin and light then and such are still their characteristics today; but, if the Wines from the Charentes vineyards have never been very fine, they yield, when distilled, a brandy of exceptional excellence and inimitable character.

The only Brandy entitled to the name Cognac is that which has been distilled from Wine produced by the Vineyards of a limited district, the Région Délimitee; this comprises the greater part of the two Départements of Charente and Charente Inférieure, and a small area in the two other neighbouring Départements of Deux Sèvres, in the north, and Dordogne, in the south.

The vineyards of the Cognac-producing district may be divided in two main classes, the Champagnes and the Bois.

On the left bank of the river Charente, 
THE VINEYARDS OF THE WORLD. 23

and in the western part of the Département of Charente, are situated the vineyards of the Grande Champagne and Petite Champagne, which produce the finest Brandies. On the opposite side of the river Charente, there is a small district known as Borderies, where Brandy of excellent quality is also made.

The soil of the Grande and Petite Champagnes is chiefly calcareous ; in the Borderies, the soil is of a similar nature, but the chalk it consists of is of a harder kind than in the Champagnes. From the Vineyards of these three districts is produced a distinctive and constant type of brandy of greater finesse and excellence than any other, and one which no connoisseur can fail to identify.

Outside these principal growths, however, the quality, flavour and distinctive properties of the brandies made in the rest and 


\section{THE VINEYARDS OF THE WORLD.}

greater part of the Région Délimitée, vary to a very considerable extent, according to the nature of the soil and the climatic conditions of each particular locality. There are a very large number of Bois of various grades and types, which are known as Fins Bois, Bons Bois, Bois Ordinaires and Bois Eloignés.

The Vines grown on clayish soil in the eastern part of the Région, and those from more western vineyards, close to the Atlantic, where the soil is very sandy and the climate damp, produce two very different types of Brandies, both, however, belonging to the same class of Bois Eloignés.

In other words, whilst Grande Champagne, Petite Champagne and Borderies are geographical expressions corresponding to the peculiar chalky soil formation of a distinctly limited area, the different Bois are geographical appellations corresponding to 
THE VINEYARDS OF THE WORLD. 25

the quality of Brandies made in specified parts of the Région Délimitée, whatever differences may exist between the soil, the climate, the aspect and the finished product of each particular growth or " terroir."

\section{Burgundy.}

The ancient province of Burgundy is represented chiefly by the Départements of the Côte d'Or, the Sâone et Loire and the Yonne. Of these, the first produces the finest Wines and owes its name to a series of hills, about 36 miles in length, which stretch from Dijon to Chalon-surSâone in the direction of the N.N.E. to S.S.W., the aspect of their vine-clad slopes being principally towards the East, South East and also South. These hills have a height of from 200 to 300 feet and consist chiefly of a very hard kind of calcareous soil whilst the sub-soil is marl and rock. 
26 THE VINEYARDS OF THE WORLD.

The Vineyards of the Côte d'Or begin generally on the upper third of the hills, never ascending to the brow, and then stretch down the incline towards the plain, and sometimes extend for a mile or two in the plain itself. The best vineyards are never in the plain nor on the upper part of the slopes but on the middle or the lower part of the inclines which are nowhere very steep. From Dijon in the north, to Santenay in the south, are to be found the finest Burgundy vineyards, all of which are in the Département of the Côte d'Or. Some five miles from Dijon is Gevrey, where Chambertin is grown; then, one passes Musigny and the world-famous ClosVougeot, where the soil is quite different from that of other Vineyards, being a mixture of lime on a sub-soil of clay. Further on is Vosnes, where are to be found the vineyards of Romanée St. Vivant, 
THE VINEYARDS OF THE WORLD. 27

Romanée Conti, La Tache and Richebourg, all of which produce most excellent wines. After Vosnes, one comes to Nuits, where the ground faces south-west and is almost flat, and then to Beaune, after passing Aloxe, chiefly famous for the produce of the Corton vineyards. After Beaune, where the old hospice may be said to reign over the vine-land of Burgundy, one comes to Volnay, Pommard, Meursault, and then to the most famous white wine vineyards of the Côte d'Or at Montrachet. Chassagne, not far from Puligny, and Santenay, on the border of the Côte d'Or, also possess many good Vineyards. In the adjoining Département of Sâone et Loire, many fair Vineyards are also to be seen and much good wine is made there, but none which can compare in quality with the best growths of the Côte d'Or. The best red wines of Sâone et Loire are 
28 THE VINEYARDS OF THE WORLD.

those of Mâcon and the best white ones those of Pouilly.

In quite another direction, the Département of the Yonne, part of which used to be within the limits of the old province of Burgundy, produces a very large quantity of red and white wines of which the white wines of Chablis are the most celebrated.

South of the Département of Sâone et Loire is that of the Rhône, where are the Beaujolais hills which, although outside the limits of Burgundy, produce an agreeable wine, lighter but not unlike the cheaper sorts of Burgundy wines.

Further south, and still on the left bank of the Rhône, at Tain, are the vineyards which produce the once famous wines of Hermitage.

In the whole of the valley of the Rhône, as well as in the whole of the south of France, from the Alps to the Pyrenees, 
THE VINEYARDS OF THE WORLD. 29

vineyards are to be seen and wine is made, but we must return northwards to other vineyards which produce a wine more popular than any other in our country: Champagne.

\section{Champagne.}

Champagne is the name of an ancient French province, where the Romans introduced viticulture and where it has flourished ever since. It is also the name of a sparkling white wine known by that name all the World over; but, although the old province of Champagne was divided in I789 into four Départements, the Ardennes, Aube, Marne and Haute Marne, all of which boast that they possess extensive vineyards and produce good wine, the better class Champagne is grown within a comparatively small area of the Marne Département only.

The grapes which produce the best 


\section{THE VINEYARDS OF THE WORLD.}

Sparkling Champagne are grown on the calcareous slopes of two distinct ranges of hills, with greatly varying aspects, north, east and south, but all possessing one common and important feature, namely, poor soil, practically all chalk, and unsuitable for any other culture.

The Champagne vineyards are usually classed into two main topographical divisions, those of the Rivière and those of the Montagne de Reims. The former are facing the river Marne and may be further divided as follows :-(I) The vineyards of the River proper, facing south, from Cumières to Avenay, and including besides these, Hautvillers, Dizy, Mareuil-sur-Ay, and Ay ; (2) The Epernay vineyards, which also include the neighbouring growths of Pierry. and Chouilly; (3) The Montagne d'Avize, a gentle range of hills beginning with Grauves and Cuis in the west and 
THE VINEYARDS OF THE WORLD. 3I

sloping towards the east as far as Vertus. From Cuis to Vertus are the finest Champagne white-grape vineyards, at Cramant, Avize, Le Mesnil and Oger. Owing to their north-easterly aspect, most of these vineyards are liable to be severely affected by late spring frosts, which are responsible for the smaller average yield per acre in that district than in any of the others of the same region.

What is known as the Montagne de Reims, is really the other side of the range of hills which faces the river Marne and divides Reims from Epernay. On the Reims side, the slopes are not nearly so steep and permit of a far greater acreage of hillside vineyards, beginning at Villedommange. To the East of this, and practically facing north, are the famous vineyards of Rilly-la-Montagne, Chigny, Ludes, Mailly, Verzenay, Sillery and Verzy. Soon after Verzy, the Montagne 


\section{THE VINEYARDS OF THE WORLD.}

comes to an end in the shape of an irregular horse-shoe or spur, and round the bend with a southern aspect, are the vineyards of Bouzy, Ambonnay and Trépail.

All the above are first growths and produce none but the best Champagne. There are, of course, a great many other less renowned vineyards within the Marne Département alone, and within the area officially delimited by the French Government, outside which no wine can be made which is to be sold as Champagne.

\section{Saumur.}

The Département of Maine et Loire, where Saumur is situated, produces a large quantity of wine, chiefly white and still, which possesses great delicacy. In mediæval times, the still white wines of Anjou were largely shipped from Nantes to England, and were greatly appreciated. We 
THE VINEYARDS OF THE WORLD. 33 only know now, in this country, the sparkling wines made on the low calcareous hills in the neighbourhood of Saumur.

\section{GERMANY.}

Antiquarian finds of Roman wine cups and wine-making implements in Germany, as well as the writings of ancient Roman historians, can leave no doubt whatsoever as to the antiquity of viticulture in Germany. It is not so generally known, however, that the trade in Rhine and Moselle Wines was flourishing in England as far back as the reigns of Edgar, Ethelred II., and Edward the Confessor.

Viticulture, in Germany, and the imports of German wines into this country have never attained and never can attain a very considerable development. Vines will only grow within a comparatively small area of the German Empire, but they still flourish 


\section{THE VINEYARDS OF THE WORLD.}

where they have been growing for many centuries past, lovingly tended by a hardworking race of wine-growers, who are assisted and encouraged by intelligent and strictly enforced laws. On the other hand, the trade in German wines in this country still holds the very honourable place which it has enjoyed for so many centuries.

The average imports of German wines in the United Kingdom, are about 600,000 gallons per annum, whilst the average total production of wine in Germany is only about fifty-four million gallons per year. We, therefore, consume over one per cent. of the wines of Germany, whilst we only receive 0.28 per cent. of the wines of France, and 0.02 of those of Italy.*

The following Table shows the number of acres planted with Vines in Igog and the

* We receive about 0.74 per cent. of the wine-production of Spain and 3.45 per cent. of that of Portugal. 


\section{THE VINEYARDS OF THE WORLD. 35}

number of gallons of wine they yielded per year, taking the average of the years 1907 . Igo8, and Igog.

Acres.

Gallons.

Alsace Lor- 73,246 yielding an average of $15,980,002$ raine

Bavaria - 52,903

Prussia - 43,472

Baden - 4I,276

Wurtemberg 39,I43

Hesse - 32,823

Other Dis- $49 \mathrm{I}$ tricts

Total $-\overline{283,354}$ $\begin{array}{rrrr} & \text { " } & \text { " } & \text { II, } 924,336 \\ \text { " } & \text { " } & \text { " } & 7,284,766 \\ & \text { " } & 8,594,978\end{array}$

" " " $\quad 4,939,284$

". " "

" , $\quad$, 93,629

or an average production per acre of :-

640 gallons in Alsace Lorraine.

552 " Bavaria.

255 " Prussia.

543 " Baden.

28 I " Wurtemberg.

297 " Hesse.

477 " other districts.

Practically the whole of the German 
36 THE VINEYARDS OF THE WORLD.

vineyards are in southern and western provinces of the Empire and the German wines shipped to this country come chiefly from three distinct districts, viz., (I) From the valleys of the Moselle and its tributaries; (2) from the valley of the Rhine; (3) from the Bavarian Palatinate.

\section{Moselle.}

The wines generally known in this country as Moselle Wines, are the produce of the finest growths of the valley of the Moselle from Treves to Coblenz, as well as of the vineyards which grace the banks of the Saar and of the Ruwer, two tributaries of the Moselle.

The valley of the Upper Moselle, before the River reaches Treves, produces a large quantity of wine, but none of superior quality, and none which can compare with the wines of the Saar. This river runs 
THE VINEYARDS OF THE WORLD. 37

mostly in a northwesterly direction, and joins the Moselle a few miles above Treves. The finest Vineyards of the Saar are on the right bank of the river from Geisberg in the South, to Euchariusberg in the North. Not far from Geisberg is Bockstein, and a little further on the famous Scharzhofberg, the finest growth of the Saar valley. Two other celebrated Bergs in the district are Scharzberg and Agritiusberg, whilst excellent wines are also made a little further north at Wiltingen and Oberemmel.

Below the ancient city of Treves, rich in Roman remains of great beauty, the Moselle receives, on the right, another small river, called the Ruwer. In the valley of the Ruwer, some very delicate and fascinating wines are also made, none better known nor more excellent than those from the ancient ecclesiastical vineyards at Grünehaus. 
38 THE VINEYARDS OF THE WORLD.

From there to Coblenz, on either bank of the Moselle, are grown the finest wines of the Moselle proper. To name but a few : there are Piesport and the range of the Brauneberg hills, on the left bank of the river; a little further down, and on the opposite bank, we come to the celebrated Berncastel vineyards, where the vines grow on distinctly slaty soil.

From Berncastel northwards, the vineyards of Graach, Josephshof, Wehlen, Zeltingen and Trarbach, on the right, and those of Erden, Machern and Uerzig, on the left, are among those which produce the most delicate Moselle wines, light without being thin, and possessing that very distinctive bouquet which is their greatest charm. The peculiar aroma of the Moselle wines is due to the silicious soil on which they are grown, which is more or less hard according to each district, but which often 
THE VINEYARDS OF THE WORLD. 39

requires blasting before the vines can be planted.

The lower valley of the Moselle offers one of the most picturesque and delightful sights it is possible to see. Nowhere in the world can more perfectly ideal scenery be found than in the Moselle valley on a fine summer day. The winding river sparkling in the sun; the steep vine-clad hills crowned with secular oaks ; the quaint little villages nestling among vineyards by the riverside ; the gable roofs of old houses closely grouped round some sturdy grey church, the grim tower of some ancient castle standing above it all on some inaccessible rock ; there is no vine-land which possesses greater beauty or greater charm.

\section{The Rhine.}

The valley of the Rhine is not so picturesque as that of the Moselle, but it has more 
40 THE VINEYARDS OF THE WORLD.

grandeur. From Bonn to Coblenz and from Coblenz to Bingen many vineyards are to be seen on either bank of the river, and much wine is made, most of which, however, is consumed in Germany. Abroad, the most celebrated Rhine wines are those of a limited district known as the Rhinegau and those of Rhenish Hessen.

The Rheingau vineyards proper are on the right bank of the Rhine and may be said to begin opposite Bingen, with the extensive vineyards of Rudesheim, and to end with the hills of Rauenthal. It is within that comparatively small area that are to be found the most famous Rheingau vineyards which yield wines second to none in the world in point of excellence and which are eagerly bought, at the vintage, at prices far higher than those given for new wines in any other vine-growing country.

After leaving Rudesheim, one comes to 
THE VINEYARDS OF THE WORLD. 4I

Geisenheim, Winkel, Mittelheim, and Oestrich, near the Rhine, whilst higher up the hills are the Castles of Johannisberg and Volrads surrounded by magnificent vineyards. A little further east are the no less celebrated hills of Steinberg, whilst nearer the river are the famous growths of Hattenheim, Marcobrunnen, Erbach and Eltville.

On the opposite bank of the Rhine, in Hessen, there are a far greater number of vineyards from Bingen to Mayence and from Mayence to Worms, than in the Rheingau, but there is only a comparatively small percentage of the wines made in this province which can claim to possess a very high degree of excellence. Some vineyards in Hessen, however, produce very fine wines, with good body and bouquet, which are eminently suited for exportation. The best of these are the wines of Nierstein and Oppenheim, some miles south of 
42 THE VINEYARDS OF THE WORLD.

Mayence, and those of Liebfraumilch, near Worms, on the southern frontier of Hessen.

As regards the tributaries of the Rhine other than the Moselle, the Ahr and the Nahe, on the left, the Lahn, the Main and the Neckar, on the right, are the most important ones. Extensive vineyards are cultivated in the valleys of all these rivers, and they produce both red and white wines in large quantity and of very good quality. Walporzheim, on the Ahr, and Hockheim, on the Main, are the two most celebrated growths of these tributaries of the Rhine, the first being famous for its red wines, and the second for its white wines. It is said that Hock, the name so generally given in England to all Rhine wines, and sometimes to all German wines, is derived from Hockheim, the wines of which have been justly popular among us for many centuries. 
THE VINEYARDS OF THE WORLD. 43

\section{Palatinate.}

The Palatinate Vineyards differ from all others in Germany, being the only ones which are not grown in sheltered valleys, on the steep slopes of the hills which border the Rhine and its tributaries. They are situated on a plateau, protected from strong winds by a mountain range, and are planted in a soil chiefly of alluvial origin mostly with southern aspects. The wines made in that district are very distinct from those of the Rheingau, being more luscious but not quite so lasting. The first growths of the Palatinate are Deidesheim and Forst; also Durkheim, Wachenheim, and Ruppertsberg.

\section{Portugal.}

Portugal, as well from its geographical position, its benignant climate, and geological conformation, as from other propitious circumstances, is admirably adapted to 
44 THE VINEYARDS OF THE WORLD.

viticulture. Vines are grown and wines are made in many parts of Portugal, but the only wines which will bear exporting are those grown in the immediate vicinity of Lisbon and in the valley of the Douro. Some 200 years ago the wines of Lisbon were more prized in London than those of Oporto, whilst we received up to the middle of the last century, a fairly large quantity of white Lisbon wines, Collares, Bucellas and Carcavellos from Portugal. Our trade in wines with Portugal is, however, now confined almost entirely to those shipped from Oporto, and the vineyards which produce Port are really the only ones which need arrest our attention.

Port is the produce of certain vineyards situated on the banks of the River Douro, within a strictly limited area. The name Port, therefore, has a well-defined geographical meaning, and does not only indicate the 
THE VINEYARDS OF THE WORLD. 45 style or quality of a wine, but also and chiefly the country and district of origin of that wine. There is some red wine made in Spain, in Cape Colony, Australia and California, which may have the same colour and the same alcoholic strength as Port, but no such wine should rightly be sold as Port, even with the adjunct of the locality it really comes from.

The hills of the Douro valley are very high and often very steep, but they are covered from base to summit with vines, chiefly planted in tiers and terraces which it has only been possible to make by cutting or blasting the hard mountain rock. Vines grown in the valleys produce less fine wine than those planted higher up the hills, though the latter, if too high up, run the risk of being scorched, the sun beating with merciless severity on the rock. 
46 THE VINEYARDS OF THE WORLD.

\section{SPAIN.}

Spain possesses a benignant climate and a generally arid calcareous soil highly congenial to the culture of the vine. From north to south and from east to west, sites, soils and aspects of the happiest kind are to be met with in every part of the country, and luxuriant vineyards are to be seen on the slopes of every hill or mountain; yet there is but a small percentage of the vinous wealth of Spain ever sent abroad, and the only Spanish wines of any commercial importance in our country, are those of Jerez and Malaga in the south and those of Tarragona in the north.

The fame of the Jerez wines in England is of great antiquity and was even greater than that of any other wine during the latter part of the sixteenth century. By an order of March I4th, I5I7, renewed in I530, the Duke of Medina Sidonia granted 
THE VINEYARDS OF THE WORLD. 47

special privileges to all Englishmen who went to Seville, Cadiz, or Jerez, to buy wines. The wine called Sack which is so often praised in Shakespeare's plays and the works of all the old poets and dramatists, was Spanish wine which chiefly came from Port St. Mary.

The same vineyards which produced the Sack of old now yield Sherry. Carbonate of lime forms about two-thirds of the soil, and the sun ripens the grapes without those hazards from frosts or excessive rains to which in more northern climes, the vintage is constantly liable.

To the east of Jerez, on the other side of the Sierras are the vineyards of Malaga, by far the most picturesque in Spain. The mountains round Malaga are clothed from the valley depths to the summits with vines, and the low-roofed houses of the peasants peep out on the acclivities around them as 
48 THE VINEYARDS OF THE WORLD.

if they had been placed by an artist's hand. Many of the vineyards are located at a great height from the level of the sea and planted on narrow terraces.

Tarragona, in Catalonia, produces a very large quantity of wines, chiefly red, which are largely exported to this country where they are of great value principally for blending purposes.

\section{ITALY.}

Italy is, after France, the largest wineproducing country of the world and it may be said to be one large vineyard from Lombardy and Tuscany in the north, down to Sicily in the extreme south.

Some sparkling wines are made on the low hills of the Asti and Montferrat region, whilst dry red wines are made in very large quantities in Tuscany. These are both pleasant and wholesome and are exported 
THE VINEYARDS OF THE WORLD. 49 to this country in comparatively small quantities which, however, tend to increase. The most renowned white Italian wines are those from the Vineyards of Capri, whilst Marsala produces a large' quantity of luscious wines of great excellence.

Switzerland, Austria Hungary, the Balkan States, Greece and Turkey, all boast more or less extensive Vineyards and produce a considerable quantity of wines, some of which are of rare excellence, such as the renowned imperial Tokay from Hungary. In the Crimea, the Caucasus and Bessarabia, there are no less than 650,700 acres of Vineyards which produce an average of $77,336,000$ gallons of wine per year.

AFrICA also possesses vast vineyards, chiefly in Algeria and Tunis in the north, and in Cape Colony in the South. 
50 THE VINEYARDS OF THE WORLD.

America possesses many vineyards. The Vine grows and wine is made in many parts of the United States, but nowhere in such quantities nor to such perfection as in California. Mexico, Peru, Bolivia and Chili, all produce a certain quantity of wine which is mostly consumed locally or in neighbouring states. On the other side of the Andes, in the Argentine Republic, the vineyards of Mendoza are the most important. Uruguay and Brazil also have extensive vineyards, but none of these South American Republics have begun exporting their wines to the Old World.

Not so, however, Australia, in whose vineyards on an average $4 \frac{1}{2}$ million gallons of wine are produced per year, a certain proportion of which being annually exported to England.

CYPRUS, the Azores, the Canaries and 
THE VINEYARDS OF THE WORLD. 5I

Madeira are the principal vineyard Islands which produce excellent wines, some of which are sent to this country every year.

This rapid survey of the Vineyards of the World teaches us that the vine is not only one of the most ancient of the plants we know, but that it is also one of the most universal. It holds a unique place in the marvellously ordained economy of our wonderful world, being at the same time the most fruitful of all plants or trees and the only one which will grow-and is meant by nature to grow-in the most barren soils. This is so true, that it may safely be asserted that the poorer the soil the better will the wine be. A poor light chalky soil such as at Cognac, Avize or Jerez; sandy, stony gravel, as in Médoc ; decomposed granite as at Hermitage; soft or hard slate as on the banks of the Moselle ; 
52 THE VINEYARDS OF THE WORLD.

hard schist or granite as in the Douro; soils which are not suitable for either corn, beet nor even grass, there will the vine grow and prosper.

On the other hand, and as a consequence of the poor soil of most vineyards, it may be asserted that no other culture requires so much individual intelligence and incessant care as does viticulture. So that the vine does not only hold a prominent position economically, rendering valuable otherwise valueless lands, but also, and chiefly socially, as a civilising agent. The vine is par excellence the plant of peaceful lands ; nomadic Arabs and roaming Gipsies sow corn and root crops but move on as soon as their harvest is gathered. Not so the vine-grower, whose patient and arduous labours can never be repaid until some years after he has planted those vines which attach him to the soil and which he 
THE VINEYARDS OF THE WORLD. 53

learns to tend with that loving and intelligent care the like of which is not to be found in any other branch of agriculture.

AVERAGE OFFICIAL PRODUCTION OF WINE PER ANNUM (1907-I908-I909).

Countries.

France -

Italy -

Spain -

Algeria -

Austria

Portugal

Hungary

Russia -

Germany

Chile

Roumania

Greece -

Bulgaria

United States of America

Turkey and Cyprus

Argentine Republic

Swiţzerlaṇd -
Number of Gallons.

- I,333,728,022

- $1,078,362,032$

- $\quad 378,935,084$

- $\quad 180,646,994$

- $\quad \mathrm{r} 36,730,792$

- $84,333,326$

- $\quad 77,183,326$

- $\quad 57,200,000$

- $\quad 56,088,75^{8}$

- $\quad 49,866,652$

- $\quad 47,666,652$

- $45,650,000$

- $45,466,652$

- $\quad 35,933,326$

- $\quad 35,200,000$

- $\quad 26,766,652$

- $\quad 22,806,520$ 
54 THE VINEYARDS OF THE WORLD. AVERAGE OFFICIAL PRODUCTION OF WINE PER ANNUM (1907-Ig08-1909).-cont.

Countries.

Number of

Servia - - - - - I2,320,000

Brazil - - - - - 8,286,652

Tunis - - - - - 6,233,326

Australia - - - - 4, 490,200

Cape Colony - - _ $\quad$ - 4, 4,228,400

Azores, Canaries, Madeira - 2,933,326

Luxemburg - - - - 2,449,326

Peru - - - - - 2,I92,652

Uruguay - - - - 2,170,652

Bolivia - - - - - 638,000

Persia - - - - - 337,326

Mexico - - - - - $\quad 293,326$

$3,739,237,974$ 
1

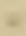


$+2+1$

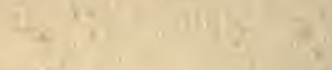

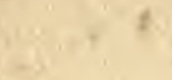

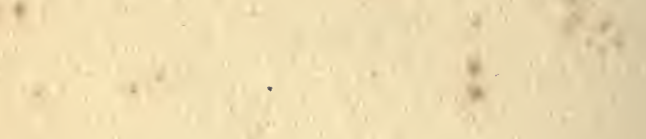

$\frac{8}{4}$

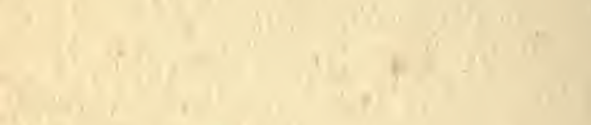

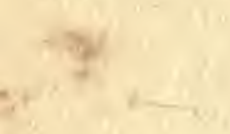

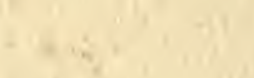

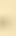

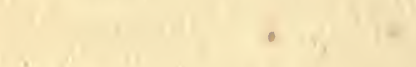

in

(1)

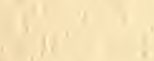

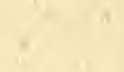


THIS BOOK IS DUE ON THE LAST DATE STAMPED BELOW

BOOKS REQUESTED BY ANOTHER BORROWER ARE SUBJECT TO RECALL AFTER ONE WEEK. RENEWED BOOKS ARE SUBJECT TO

DUE NOV 21981 NOV 51981 REC'

UG 18 1982 REC'R

UUE JUN 301993 IUN 221993 PEY
U C D LIBRARY

DUE MAR - 61994 MIAK 18 1994 REC'D

LIBRARY, UNIVERSITY OF CALIFORNIA, DAVIS 


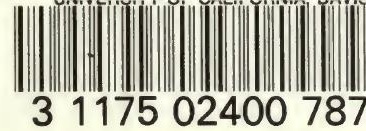


